\title{
Environmental Accounting Practices and Corporate Performance: Study of Listed Oil and Gas Companies in Nigeria
}

\author{
ILIEMENA, RACHAEL O. \\ Department of Accountancy, Nnamdi Azikiwe University, Awka, Nigeria
}

\begin{abstract}
This study investigated the effect of environmental accounting practices on corporate performance of listed oil and gas companies in Nigeria, 2012-2018. This was achieved through the formulation of Hypotheses which we tested using data obtained from stock exchange fact books, corporate sustainability reports and annual reports of sample firms. Ex-post facto research design was employed in the study and the analysis carried out using simple linear regression. Findings reveal environmental accounting practices and accounting have significant positive effects on both turnover and Return on capital employed; while the effect on net profit even though positive, was insignificant. The theoretical outcome of this study is the Performance Improvement Theory (PIT) which states that firms are involved in sustainability accounting generally for the reason of improved corporate performance benefit drivable through good reputation and cost reduction. Our study concluded that, environmental accounting has significant positive effect on corporate performance of practicing companies. It is therefore recommended amongst others that corporate organizations should extend their management accounting and financial reporting systems to environmental accounting as a way of ensuring long-run corporate sustainability.
\end{abstract}

Index terms: Environmental accounting, Corporate Performance, Performance improvement (PIT) theory.

DOI: $10.7176 / \mathrm{EJBM} / 12-22-08$

Publication date:August $31^{\text {st }} 2020$

\section{INTRODUCTION}

The turn of events in corporate sustainability and growth has brought about demands for Stakeholder based accounting and reporting. The success of every corporate organisation is $80 \%$ dependent on its operational environment as no business can survive without the environment. The role of the environment and its proven immense contribution to the continued success of corporate organisations, have necessitated the concept of environmental accounting as part of corporate accounting system. A study by Amedu, Iliemena, and Umaigba (2019) revealed that most Nigerian manufacturing companies are silent on environmental information disclosure. Accounting for environment helps in accurate assessment of costs and benefits of environmental preservation measures of companies (Schaltegger, 2000). Environmental accounting is an inclusive aspect of sustainability accounting and reporting, thus, generates reports that provide environmental information to help make internal management decisions and external use by stakeholders.

The severity of environmental problems in Nigeria and beyond is known to have negative effects on life expectancy generally. According to Yakhon and Dorweiler (2004), the impact of business activities on the environment is found in several forms which include air, water, underground pollution, drinking water, land and habitat for endangered and threatened species, oceans, atmosphere, and land pollution. As it is notable that organisational processes give rise to industrial pollution, deforestation, oil spillage, and gas flaring, measures are being taken both at the national and international level to curtail its economic, social and health impacts generally. Environmental accounting rules or environmental disclosure guidelines, for communication to different stakeholder groups, are not available for Nigerian companies; however, there have been some effort on the part of government towards enacting acts and laws to enhance environmental sustainability in Nigeria. These include Environmental Impact Assessment Act 2004, Environmental Guidelines and Standards for petroleum industry 2002, National Environmental Standards and Regulations Enforcement Agency Act 2004. However, corporate organisations that practice environmental accounting adopt certain principles deducible from the Global Reporting Initiative (GRI) Guidelines. In order words, there is no mandatory requirement for quantitative or qualitative disclosure of (financial) environmental accounting information in annual reports neither under the Companies and Allied Matters Act (CAMA) nor as per International Accounting Standards (IAS's) or International Financial Reporting Standards (IFRS). Furthermore, there is no mandatory Stock Exchange listing requirement for Nigerian companies, to disclose environmental accounting information although the Nigerian Stock Exchange in its recent Guideline (2018) issued on sustainability reporting advised the disclosure of corporate environmental events. Hence, disclosure of environmental accounting information in Nigeria is more of voluntary reporting which does not encourage environmental accounting. Studies conducted by Amedu, Iliemena and Umaigba (2019) reveal that environmental sustainability reporting information is not value-relevant. Thus, one begins to wonder the implication on financial performance. According to Murray (2010) it is counter intuitive to think that companies would undertake expenditures on social and environmental impacts knowing that there would be no return. It is argued by proponents that additional costs associated with environmental accounting and disclosure depresses the 
profitability of the reporting company. This study is therefore aimed to determine the effect of environmental accounting on corporate performance. In order words, our present study seeks to specifically provide answers to the below questions;

1. What is the effect of environmental accounting on turn over?

2. How does environmental accounting affect Return on Capital Employed?

3. To what extent does environmental accounting affect Net profit margin?

\section{LITERATURE REVIEW}

\section{Concept of Environmental Accounting (EA)}

Environmental Accounting (EA) represents the incorporation of environmental costs into the accounting system of a business organisation. According to KPMG and UNEP (2006), EA is a system that provides a common framework for organizations to identify and account for past, present and future environmental costs to support managerial decision-making, control and public disclosure. EA has been referred in a variety of ways in different literature: environmental management accounting, corporate social accounts, social accounting, social and environmental accounting (Cooper,Taylor, Smith, \& Peterson, 2005). These however, have not changed the meaning as all drive towards quantifying environmental expenditure. The practice of Environmental accounting helps an organization to quantify the impacts of its activities on the host community. This does not involve only the expenses incurred but also the cost benefits generated in an accounting period. Environmental accounting information include information regarding treatment of chemicals generated in a production process, labour cost (embedded in salaries and wages), disposal costs, fines and penalty costs or savings, regulatory fees, maintenance costs, cost savings in switching to more environmentally friendly methodologies, materials costs etc. The manners in which firms apply environmental accounting differ depending on activities engaged in the period and the management decisions on what should constitute cost information. Environmental accounting processes basically generate two categories of information as below;

\section{Fig. 1: Categories of Environmental Accounting Information}

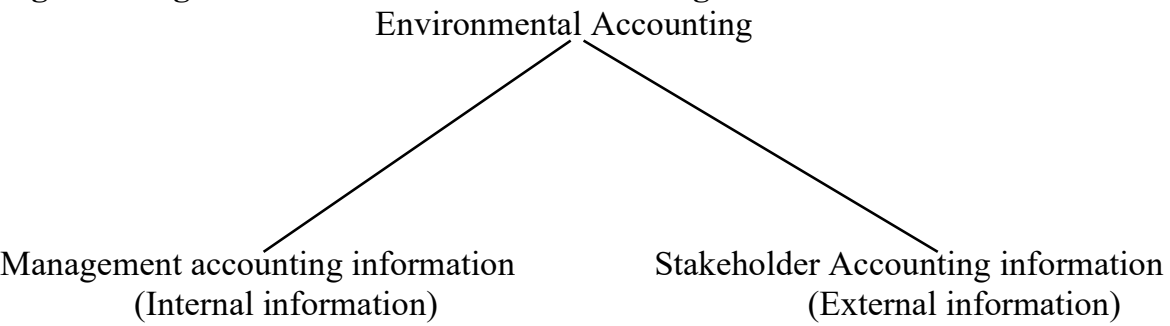

A. Environmental Management Accounting provides a platform whereby relevant information regarding environmental costs and benefits are communicated to the management of an organisation. The essence of this is to provide information to management which will enhance internal decision making processes. These decisions range from decisions regarding product cost, design, pricing, capital investments and asset acquisition decisions, facility sitting decisions, waste management or disposal, material acquisition and usage, etc. The role of environmental accounting here is to identify, separate, measure, quantify and interprets the relevant environment costs and report to the management as appropriate. The inclusion environmental cost information in the accounting framework ensures the prices are commodities are not underpriced or overpriced as it ensures the prices of commodities include all necessary internal and external costs and benefits incurred and generated in the period to keep the product in the market. the identification of environmental cost items help in proper management of the costs The different techniques which can be applied in identification and allocation of environmental costs include flow cost accounting, input-output analyses, full-cost accounting, activity-based costing (ABC), and lifecycle costing and Activity Based costing. The information outcome of this is referred to as internal information because it is only relevant for management use.

- Flow-cost Accounting: flow cost accounting is a system that allows the quantification of costs relating to the material inflow into an organisation system and delivery and the disposal of the material into the environment. Literature classifies material flow costs as relating to;

\section{Fig 2: Material flow}

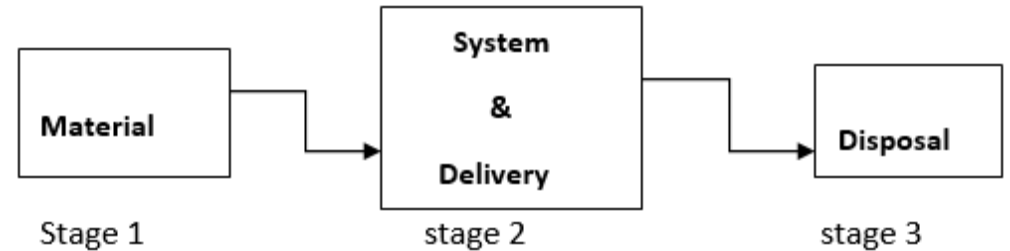

As material flows from stage one to the third stage as in figure 1, it generates costs. Environment accounting 
attaches value to the cost items which are added to the actual material cost. The aim is to capture costs associated with waste and energy usage. The level and amount of total material cost is dependent on the volume of material flow in the period and its overall environmental impact as it flows from stage 1 to stage 3 .

- Input/output Analysis: is an accounting system that compares the material input into an organisations process with what the organisation generates and gives out as output at the end of a production process. In a production process which generates less output compared to its input, the shortfall could have been waste disposed in the environment or scrap sold to the environment. Environment accounting system enables this shortfall or excess (where applicable) to be accounted for and reported accordingly.

- Activity Based Costing: Activity Based Costing focuses on elements that cause an overhead cost to be incurred. The elements are known as cost drivers. The use of ABC in environmental accounting traces environmentally driven costs which are potentially hidden in the general overhead and accounts for such based on their environmental cost drivers.

- Lifecycle costing: lifecycle costing in environmental accounting requires that costs relating to the environmental consequence of a product be captured throughout the product lifecycle. The lifecycle of a product is starts from the introduction of the products, growth, maturity and finally decline. The costs of the environmental impact of the product is captured and valued in environmental accounting from introduction to decline.

B. Environmental Stakeholder Accounting is a system of environmental accounting which forms part of financial statement reporting. This is also referred to as environmental financial accounting. The essence of environmental accounting here is to provide relevant environmental information for stakeholder-based reporting. This is by way of gathering and reporting to the stakeholders on the direct and indirect impact of the organisations activities on the environment. The information so provided forms part of financial accounting information which is to be published in the annual financial statements or forms part information in stand-alone annual sustainability reports. Shareholders and potential shareholders make investment or disinvestment decisions based on information published in annual financial reports (Iliemena \& Okolocha, 2019). The stakeholders of an organization include investors, employees, lenders, suppliers, government, local communities, shareholders and management. The Global Reporting Initiative provides reporting standards and guidelines which require that environmental accounting information be provided with respect to;

Material

- Materials used by weight or volume

- Percentage of materials used that are recycled input materials

Energy

- Energy consumption within the organization

- Energy consumption outside of the organization

- Energy intensity

- Reduction of energy consumption

- Reductions in energy requirements of products and services

Water

- Total water withdrawal by source

- Water sources significantly affected by withdrawal of water

- Percentage and total volume of water recycled and reused

Biodiversity

- Operational sites owned, leased, managed in, or adjacent to, protected areas and areas of high biodiversity value outside protected areas.

- Description of significant impacts of activities, products, and services on biodiversity in protected areas and areas of high biodiversity value outside protected areas.

- Habitats protected or restored

- Total number of IUCN red list species and national conservation list species with habitats in areas affected by operations, by level of extinction risk.

\section{Emissions}

- Direct greenhouse gas (GHG) emissions (scope 1)

- $\quad$ Energy indirect greenhouse gas (GHG) emissions (scope 2)

- Other indirect greenhouse gas (GHG) emissions (scope 3)

- Greenhouse gas (GHG) emissions intensity

- $\quad$ Reduction of greenhouse gas (GHG) emissions

- Emissions of ozone depleting substances (ODS)

- NOx, SOx, and other significant air emissions 


\section{Effluents and wastes}

- Total water discharge by quality and destination

- Total weight of waste by type and disposal method

- Total number and volume of significant spills

- Weight of transported, imported, exported, or treated waste deemed hazardous under the terms of the basel convention and percentage of transported waste shipped internationally

- Identity, size, protected status, and biodiversity value of water bodies and related habitats significantly affected by the organizations' discharges of water and runoff

\section{Products and services}

- Extent of impact mitigation of environmental impacts of products and services.

- Percentage of products sold and their packaging materials that are reclaimed by category

\section{Compliance}

- Monetary value of significant fines and total number of non-monetary sanctions for non-compliance with environmental laws and regulations

\section{Transport}

- Significant environmental impacts of transporting products and other goods and materials for the Overall organizations' operations, and transporting members of the workforce.

- Total environmental protection expenditures and investments by type

\section{Supplier environmental assessment}

- Percentage of new suppliers that were screened using environmental criteria

- Significant actual and potential negative environmental impacts in the supply chain and actions taken.

- Number of grievances about environmental impacts filed, addressed, and resolved through formal grievance mechanisms.

\section{The need for Environmental Accounting Practices for oil and gas companies in Nigeria}

Nigeria as a developing nation with her abundant natural resources (Oil and Gas products) is facing difficult challenges in the control of environmental degradation. Oil exploration activities have reduced the quality and usefulness of life through gas flaring, industrial pollution, oil spillage, deforestation, global warming, and other related issues of health concern. Although, the country derives huge amount of money daily from the sale of crude oil and it's by-products, one would generally assume that this money if properly managed should have significant impact on the development of oil and non-oil producing areas of the country. The Researcher observes that most of the oil producing communities continues to dwell in abject poverty, despite the fact that the huge amount of the nation's resources is obtained from their community. The multi-national companies that explore the crude oil and its by-products from these communities often fail to consider that they should pay adequate attention to the social demands of the host communities and become environmentally friendly with them. The hydrocarbons which are emitted into the air whenever there is oil spillage or leakages are not just dangerous to man but also dangerous to other living organisations ( aquatic animals, plants and land animals). The oil producing communities often find it very difficult to cope with their natural environment because of the pollutants generated by these corporate organisations. The pollutants according to Mabogunje (2007) include benzene which on chronic exposure may cause leukaemia and birth defects, ethlybenzene which may cause dizziness, slower reflexes, loss of consciousness and death; zylene may cause damages to a developing foetus, liver, kidney, skin, eyes, and bone marrow.

The impact of environmental pollution to the host communities cannot be over-emphasized. In line with the stakeholder theory, one would ask if the multi-national companies are doing their best to ensure enhancement of quality of life of the host communities. These entail providing the communities with good drinking water as an alternative to their already polluted water, construction of good roads to enhance community development, health care centres, schools, electricity, offering employment opportunities for indigenes of the host community, and finally ensure adequate environmental control measures in line with international and local regulatory laws. Social and environmental accounting and reporting is an aspect of sustainable development reflecting concerns about environmental protection, inter-generational equality, the earth and its resources (Henderson \& Pierson, 2004).

Environmental costs for oil producing companies constitute a certain percentage of their total production cost. It is the process of environmental accounting that these costs are quantified and measured. When environmental accounting is ignored, it could be detrimental to the firm in the face of increasing environmental regulations with increase in fines and penalties for environmental violations. The articulation of environmental costs into the accounting system will not only help to control and manage environmental costs but earns good reputation for the reporting entity as stakeholders have become increasingly aware of their process hazards.

Although recently, companies are beginning to realize that environmental consciousness is the key to corporate survival, thus, more companies are reported to be involved in one environmental event or the other 
(Example; scholarship awards, employment of indigenes, increased staff pay for risk, etc.) which is also reflected in the financial statements, even though the extent of disclosure differ. In-depth environmental accounting and disclosure practices are required given the turn of events. There is need to bring to the fore, the overall effect of this practice on corporate performance. Nigerian companies are expected to build in environmental policies as part of their corporate policies. This will help to regulate their activities and provide the motivation for environmental accounting. The information needed for environmental accounting can be sourced from the environmental initiatives executed in an accounting period. The environmental initiatives of a company are in pursuit of its environmental policy which will also help in achieving the overall organisational goal. This is illustrated in table 1 below:

Table 1: Environmental Initiatives for Environmental Accounting Information

\begin{tabular}{|c|c|c|}
\hline $\begin{array}{l}\text { COMPANY } \\
\text { NAME }\end{array}$ & ENVIRONMENTAL POLICY & ENVIRONMENTAL INITIATIVE \\
\hline EXXONMOBIL plc & $\begin{array}{l}\text { To consider risk at every stage of } \\
\text { development, and continuously } \\
\text { work to manage environmental } \\
\text { impacts. }\end{array}$ & $\begin{array}{l}\text { Environmental management process which } \\
\text { identifies environmental and social aspects, } \\
\text { evaluates social and regulatory settings, conduct } \\
\text { environmental and social risk assessment, apply } \\
\text { environmental and social aspects, monitor and } \\
\text { evaluate environmental impacts, manage risks by } \\
\text { avoidance, reduction and remedy }\end{array}$ \\
\hline CONOIL PLC & $\begin{array}{l}\text { Emphasizes highest concern and } \\
\text { commitment for the health and } \\
\text { safety of employees, customers, } \\
\text { neighbours and conservation and } \\
\text { enhancement of the environment }\end{array}$ & $\begin{array}{l}\text { Customized training programmes, awareness } \\
\text { campaigns, and safety and security audits. }\end{array}$ \\
\hline OANDO PLC & $\begin{array}{l}\text { Continuous development of } \\
\text { systems and solutions that monitor } \\
\text { their practices and operations in } \\
\text { order to prevent the crystallization } \\
\text { of environmental risks inherent in } \\
\text { their operation. }\end{array}$ & $\begin{array}{l}\text { Compliance with regulatory standards and limits } \\
\text { relating to water conservation, air pollution and } \\
\text { other environmental indicators. Construction of } \\
\text { schools, electrification projects, water projects, } \\
\text { road constructions, }\end{array}$ \\
\hline $\begin{array}{l}\text { TOTAL NIGERIA } \\
\text { PLC }\end{array}$ & $\begin{array}{l}\text { To ensure health and safety of } \\
\text { people, protection of the } \\
\text { environment and quality delivery of } \\
\text { their products. }\end{array}$ & $\begin{array}{l}\text { Community grievance management systems on } \\
\text { land, environment, employment, } \\
\text { logistics and transport, and environmental } \\
\text { hazards and Employee behaviour. }\end{array}$ \\
\hline FORTE OIL PLC & $\begin{array}{l}\text { To create and maintain a strong } \\
\text { health, safety, environmental and } \\
\text { quality culture by putting the safety } \\
\text { and security of their people, } \\
\text { protection of human health and the } \\
\text { environment, product stewardship } \\
\text { and customer satisfaction, } \\
\text { stakeholder engagement, and } \\
\text { operational excellence at the } \\
\text { forefront of all their operations. }\end{array}$ & $\begin{array}{l}\text { Undertake process safety reviews and planned } \\
\text { general inspections to identify hazards, assess } \\
\text { risks and define risk reduction measures to } \\
\text { minimize accidents and assure loss prevention } \\
\text { and continual improvement of their processes. }\end{array}$ \\
\hline ETERNA PLC & $\begin{array}{l}\text { Maintenance of good quality } \\
\text { relationship with communities by } \\
\text { good safety health, environment, } \\
\text { and security policies in all their } \\
\text { operations. }\end{array}$ & $\begin{array}{l}\text { Investments in clearer energy products to } \\
\text { complement global efforts to reduce emissions } \\
\text { and damage to the environment and also } \\
\text { investments in scientific approaches to ensure } \\
\text { that they produce best quality at affordable prices }\end{array}$ \\
\hline $\begin{array}{l}\text { MRS OIL } \\
\text { NIGERIA PLC }\end{array}$ & $\begin{array}{l}\text { Conducting of its business in a } \\
\text { manner that protects people, } \\
\text { property and the environment. }\end{array}$ & $\begin{array}{l}\text { Prevention through constant risk assessments and } \\
\text { appropriate risk management. Involvement in } \\
\text { promotion of safe and healthy working } \\
\text { environment. }\end{array}$ \\
\hline
\end{tabular}

Source: Corporate Websites 2020

A review of the annual financial statements reveal most of the companies have adjusted to incorporate disclosures regarding environmental management, bio-diversity and ecosystem services, water management, spill performance, air emissions, and decommissions while most of the above companies notably issued sustainability reports which contained their environmental accounting information. 


\section{Measuring Corporate Performance}

Corporate performance can be looked at, as the level of performance of an organization at a point in time. This could be measured in terms of overall profits and losses or asset utilization. According to Iliemena and Okolocha (2019) the measures of financial performance of an organization are as varied as the motive for the measurement. Corporate performance is measured to give the account of stewardship by the management team to the shareholders. The key aspect of this involves measuring the profitability, market value and growth prospect of a company. The measurement of the effect of environmental accounting on performance examines the nature of the relationship between some indicator of environmental reporting or performance with the company's Financial Performance obtained from the accounting information such as the historical audited financial statements of the respective companies. Financial performance is commonly used as an indicator of a firm's financial health over a given period of time. Corporate performance can be defined or measured in various ways including profitability, increase in turnover, gauge return, market share growth, return on investment, return on equity, return on capital employed and liquidity measures.

In this study, corporate performance is measured by percentage change in turnover (sales revenue) as it is expected that good environmental practices and the disclosure of environmental cost information will ultimately increase patronage, return on capital employed, and Net profit margin. As noted by Iliemena and Amedu (2019), the survival of contemporary manufacturing concerns in Nigerian $21^{\text {st }}$ century can be said to largely depend on the efficiency of its management. While management efficiency can be measured in a lot of ways including the profitability or reported profit, this can only be achieved through implementation of adequate policies to cut down operating costs (Iliemena \& Amedu, 2019). A firm can, by being environmentally sustainable, differentiate its products and thus increase its turnover. Similarly, a firm can save costs on resources, regulatory costs, capital and labour and wherefrom increase its net profits and return on capital employed. Environmentally friendly organisations generate cost savings on environmental litigations, which also add to corporate profitability.

Fig. 3: Trend in Corporate Performance 2012- 2018 using indices of change in Turnover, ROCE and Net Profit in percentages.

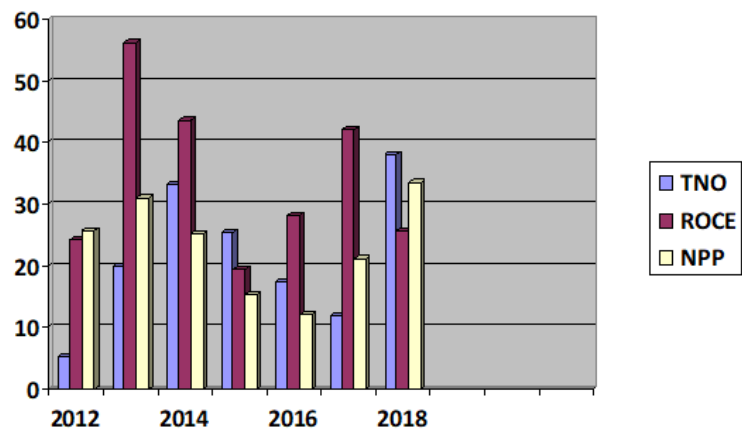

The above figures indicate the percentage change in turnover for the oil and gas companies was highest in 2018. Also, the companies generated highest levels of net profit margin in 2018 while ROCE had its highest in 2013 which also fluctuated from 2014 to somewhat stable average in 2018. These changes could have been influenced by environmental reporting practices as attention to environmental impact has improved over the years. All indices are noted to have declined between 2014 and 2016. This can easily be explained as the effect of general economic downturn.

\section{Empirical Reviews}

There have been studies in the area of environmental accounting globally as efforts are being made to promote environmental consciousness among corporations;

In Australia, Tilt (2001) studied the pattern of environmental disclosure among Australian firms. Evidence gathered in the study shows that even where a firm has a specific corporate environmental policy, they place a low priority on reporting environmental performance data to external parties. This implies that Australian firms prefer to disclose their activities and specific programs, rather than their research and development, capital expenditure, policies or performance. Also, in the Australian context, Cowan and Gadenne (2005) conducted a study which employed content analyses in interpretation of the financial statement information disclosure. There research found a tendency by their sampled Australian firms to disclose higher levels of positive environmental news. Further in 2006, Mitchell, Percy and MCkinlay examined the environmental disclosures of twenty Australian firms subject to a successful EPA prosecution between 1994 and 1998 using content analysis. Results reveal that the disclosures made by the sampled firms were predominantly positive in nature.

In Canada, Bewley and Li (2000) examined the environmental disclosures of Canadian manufacturing firms. Their study relied on voluntary disclosure theory and used Wiseman index to measure the 1993 annual report disclosures of 188 firms. Industry membership was also used to proxy for pollution propensity. The study found 
that firms with a higher pollution propensity and greater media coverage of their environmental performance are more likely to disclose general environmental information.

In America, Hughes, Anderson and Golden (2001) examined environmental disclosures made by U.S. manufacturing firms between 1992 and 1993 using a modified Wiseman index to measure disclosures in the president's letter, MD\&A, and notes sections of the annual report, and the CEP rankings to proxy for environmental performance. Their investigation revealed that firms rated as poor by the CEP generally make the most disclosures of environmental cost information. Freedman and Patten (2004) examined the financial statement report on environmental disclosures of 112 US companies in terms of their disclosure under the 1986 Toxic Release inventory regulations. The study adopted the event study methodology. The findings of these studies reveal that entities that exposed those environmental events experienced negative market reactions, those entities with higher levels of environmental reporting prior to the event suffered less negative reactions than those entities with less environmental reporting.

In UK, Murray, Sinclaire, Power and Gray (2006) investigated the relationship between UK companies' social and environmental performance disclosure and their financial market performance. The sample of the study was made up of 100 of the UK's largest companies. Social and environmental disclosure was measured by the total number of pages of voluntary and mandatory social and environmental disclosure by the companies in their annual reports over a period of 10 years using cross-sectional analyses. Findings reveal a convincing relationship between consistently high returns and high levels of social and environmental disclosure while low market returns is also found to be associated with low social and environmental disclosure practices.

In Malaysia, Malcolm (2007) examined the extent to which the environmental disclosures in annual reports of companies listed on the Kuala Lumpur Stock Exchange are associated with corporate characteristics. A rating system for environmental disclosures was developed, based on a review of previous studies, embracing industry membership, financial performance, share price fluctuations, political cost proxies, dependence on debt and the capital market. The findings suggested that environmental disclosure is negatively associated with company financial performance. Norhasimah (2016) investigated the effect of environmental disclosure on financial performance in Malaysia using the Malaysian public limited companies. Using a sample of a sample of 100 companies, the study observed that there is a significant relationship between total environmental disclosure and profit margin.

In Indonesia, Setyorini and Ishak (2012) examined corporate social and environmental disclosure on a positive accounting theory view point. The study used descriptive research design with secondary data. The population of the study was listed companies on the Indonesian stock exchange from 2005-2009. The study applied sampling method on the sectors of the listed companies in the Indonesian stock exchange. There was approximately 336 to 398 companies' listed Indonesian stock exchange. The findings reveal that when the association is driven more by political cost considerations, it can be expected that corporate social and environmental disclosure is positive associated with earnings management.

In Bahrain, Juhmani (2014) conducted a study which aimed to ascertain the extent of social and environmental reporting among listed companies in various economic sectors. The results of their study among others showed that while over $50 \%$ of the sample of listed companies provided social and environmental information in their 2012 annual reports and their websites, Commercial banks and insurance companies made the most disclosure of social and environmental accounting. The study further found that the least disclosure was made by companies in the hotels and tourism sector and industrial sector even though firms in tourism and industrial sectors generate more waste than their counterparts in financial institutions.

In Pakistan, Ahmad, Waseer, Hussain and, Ammara (2018) investigated relationship between environmental accounting and non-financial firms' performance listed in Pakistan stock exchange, Pakistan. This study used regression analysis technique (REM), using companies' annual data from 2006-2016. The empirical analysis showed a significant positive relationship between environmental accounting and firm's size. While, earning per share and return on capital employed statistically turned out to be insignificant.

In the Nigerian scene, Okoye and Ezejiofor (2013) conducted an appraisal of the relationship between sustainability environmental accounting and corporate performance of Nigerian firms using simple correlation analytical technique. Primary data was used for the study as gathered using questionnaires distributed to 25 respondents from finance sections of the two manufacturing companies judgmentally selected as Innoson Nigeria plc Nnewi and Nigerian Bottling company plc Enugu. Findings reveal that there is relationship between sustainable environmental accounting and increase in corporate productivity to enhance corporate growth and there is a relationship between sustainable environmental accounting and economic performance of a corporate organization. Adediran and Alade (2013) investigated if there is any significant relationship between environmental accounting and corporate performance in Nigeria using Return on Capital Employed (ROCE); Net Profit Margin (NPM) Divided per share (DPS) and Earnings per Share (EPS). Data for the study were secondary data generated from Annual Reports and Accounts of Fourteen (14) randomly selected companies quoted on the Nigerian stock exchange for the year 2010 and analysed using multiple regression analysis . Result shows that there is significant 
negative relationship between environmental accounting and Return on Capital Employed (ROCE) and Earnings per Share (EPS) and a significant positive relationship between Environmental Accounting and Net Profit Margin and Dividend per Share. Olayinka and Oluwamayowa (2014) investigated the aggregate and individual impact of corporate environmental disclosure on market value using descriptive research design and secondary data. The sample constituted 50 companies on Nigerian Stock Exchange purposively selected while hypotheses were tested using correlation co-efficient. Their study revealed that the inclusion of environmental information will enhance market value. Nze, Okoh and Ojeogwu (2016) assessed the effect of corporate social responsibility on earnings of two quoted Nigerian Stock Exchange oil and gas firms (2010-2014). Data for the study were sourced from the published annual financial statement of companies and the analyses done using simple linear regression technique. Results revealed corporate social responsibility has positive and significant effect on earnings.

More recently, Eboh and Chukwuka (2018) conducted an empirical investigation into the effect of green business practices on organizational performance of selected manufacturing firms in Nigeria. Simple random sampling technique was used in selecting the 10 manufacturing firms with a sample size of 543 respondents was determined from the population of 5705 drawn from management, middle and lower cadre of the selected manufacturing firms using Cochran (1977) statistical formula. Data were analyzed and the hypotheses were tested using linear regression analysis. Findings revealed that green business initiatives had significant and positive effect on the selected manufacturing firms' productivity, which indicates that the implementation of green business practices, principles and processes will lead to very positive outcome that will be visibly manifested in the organization and the environment. Iliemena and Ijeoma (2019) examined the effect of Sustainability reporting on financial performance of manufacturing firms quoted on the Nigerian stock exchange using secondary data from annual reports and accounts of 24 sampled quoted manufacturing companies. The study period ranged from 2012 to 2018 which represents IFRS reporting period in Nigeria. The three hypotheses formulated were tested using regression analyses at 5\% level of significance. Findings reveal among others that there is no significant effect of environmental disclosure on return on capital employed (ROCE). Amedu, Iliemena and Umaigba (2019) also evaluated the value relevance of the three dimensions of sustainability reporting information using primary data and found environmental sustainability reporting which is an ouput of environmental accounting not value relevant.

\section{Research gap}

Since the inception of environmental accounting and reporting, the topic has been receiving attention from both academic and non-academic Researchers globally. Empirical studies have revealed most of these studies concentrated on developed countries and very few studies focused on developing countries such as Nigeria. Generally on the relationship between environmental accounting disclosure and corporate performance, studies have reported mixed results. Some studies reported positive association while others have reported negative association which could be due to differences in country of study or the study period. However, there is dearth of literature regarding the impact of Corporate Environmental accounting Disclosures on corporate performance attributes with evidence from Nigeria. More studies are needed based on developing countries and using different measures of corporate performance to establish the relationship between environmental accounting and corporate performance, most specifically, from a developing country such as Nigeria. Also, the previous studies relied on 'ancient' Stakeholder theory, Legitimacy theory and Agency theory which may not be recently applicable due to changes overtime. Our study is therefore set out to fill these gaps identified and thus provide theoretical justification for the effect of environmental accounting on corporate performance.

\section{METHODOLOGY}

Ex-post facto research design was employed in the study. The population of this study is made up of oil and gas companies which are listed on the Nigerian Stock Exchange as at 17th July 2019: these are listed below; MOBIL plc, ANINO international PLC, CAPITAL OIL PLC, CONOIL PLC, ETERNA PLC, FORTE OIL PLC, JAPAUL OIL PLC, MRS OIL NIGERIA PLC, OANDO PLC, RAK UNITY PET. COMP. PLC, SEPLAT PETROLEUM DEVELOPMENT COMPANY LTD., TOTAL NIGERIA PLC. Judgemental sampling was applied to select those companies with complete financial statements from 2012 - 2018. Thus the sample of study consisted of 10 companies out of 12 with Rak unity petroleum plc and Japaul oil Plc eliminated from the sample group. Our current study utilized secondary data obtained from published corporate performance in annual financial statements. Additionally, necessary documents and records on environmental accounting disclosure were also utilized in the course of this study. We placed emphasis on the disclosure of information regarding material usage, energy usage and environmental compliance to denote practice of environmental accounting (marked 'Yes').

\section{Model specification}

The following simple linear regression model examines the effect of the independent variable (Environmental Accounting, EVA) measured by MAA, ENA and ECA on the dependent variable (Corporate Performance, CP) 
measured by TNO, ROCE and NET

$\mathrm{CP}=\mathrm{f}\left(\right.$ MAA, ENA, ECA $\left.\mathrm{t}_{\mathrm{t}-1},\right) \mathrm{e}_{\mathrm{t}}$

This model is restated in statistical form as follows:

$\mathrm{CP}=\mathrm{b}_{0}+\mathrm{b}_{1} \mathbf{M A A}+\mathrm{b}_{2} \mathrm{ENA}+\mathrm{b}_{3} \mathbf{E C A}+\mathrm{e}_{\mathrm{t}}$

Where:

MAA $=$ Material Accounting, ENA = Energy Accounting, ECA = Environmental Compliance Accounting, TNO = change in Turn Over, ROCE = Return on Capital Employed, NPP = Net Profit percentage, $e_{t}=$ Stochastic or error term.

Table 2: Disclosure of Environmental accounting Information in the financial statement or sustainability Reports of Companies.

\begin{tabular}{|l|l|l|l|l|l|l|l|}
\hline NAME OF COMPANY & $\mathbf{2 0 1 2}$ & $\mathbf{2 0 1 3}$ & $\mathbf{2 0 1 4}$ & $\mathbf{2 0 1 5}$ & $\mathbf{2 0 1 6}$ & $\mathbf{2 0 1 7}$ & $\mathbf{2 0 1 8}$ \\
\hline MOBIL plc & Yes & Yes & Yes & Yes & Yes & Yes & Yes \\
\hline CONOIL PLC & Yes & Yes & Yes & Yes & Yes & Yes & Yes \\
\hline OANDO PLC & Yes & Yes & Yes & Yes & Yes & Yes & Yes \\
\hline TOTAL NIGERIA PLC & Yes & Yes & Yes & Yes & Yes & Yes & Yes \\
\hline FORTE OIL PLC & Yes & Yes & Yes & Yes & Yes & Yes & Yes \\
\hline ANINO international & Yes & Yes & Yes & Yes & Yes & Yes & Yes \\
\hline CAPITAL OIL PLC & Yes & Yes & Yes & Yes & Yes & Yes & Yes \\
\hline SEPLAT PLC & Yes & Yes & Yes & Yes & Yes & Yes & Yes \\
\hline ETERNA PLC & Yes & Yes & Yes & Yes & Yes & Yes & Yes \\
\hline MRS OIL NIGERIA PLC & Yes & Yes & Yes & Yes & Yes & Yes & Yes \\
\hline
\end{tabular}

Source: Researchers' fieldwork 2019

EMPIRICAL ANALYSES AND DISCUSSIONS

Ho1: Environmental Accounting does not have significant effect on turn over.

ANOVA $^{b}$

\begin{tabular}{|c|c|c|c|c|c|}
\hline Model & Sum of Squares & Df & Mean Square & \multicolumn{2}{|c|}{\begin{tabular}{l|l}
$F$ & Sig.
\end{tabular}} \\
\hline 1 Regression & .7481 & 3 & 5.916 & .381 & $.0081^{\mathrm{a}}$ \\
\hline Residual & .2185 & 2 & 15.542 & & \\
\hline & .9666 & 5 & & & \\
\hline
\end{tabular}

a. Predictors: (Constant): MAA, ENA, ECA

b. Dependent Variable: TNO

Coefficients

\begin{tabular}{|c|c|c|c|c|c|}
\hline \multirow[b]{2}{*}{ Model } & \multicolumn{2}{|c|}{ Unstandardized Coefficients } & \multirow{2}{*}{\begin{tabular}{|l|} 
Standardized Coefficients \\
Beta
\end{tabular}} & \multirow[b]{2}{*}{$\mathrm{T}$} & \multirow[b]{2}{*}{ Sig. } \\
\hline & B & Std. Error & & & \\
\hline 1 (Constant) & 3.775 & 35.120 & & 3.92 & .033 \\
\hline MAA & 2.508 & 2.412 & .799 & 1.039 & .048 \\
\hline ENA & 6.283 & .000 & .612 & .795 & .510 \\
\hline ECA & .003 & .013 & .154 & .265 & .816 \\
\hline
\end{tabular}

a. Dependent Variable: TNO

The general linear equation is given as follows

$\mathrm{TNO}=3.775+2.508 \mathrm{MAA}+6.283 \mathrm{ENA}+0.003 \mathbf{E C A}$

The result above shows that as environmental accounting increases, turnover increases indicating positive effect at a significant level of 0.03 less than 0.05 . Also the regression model predicts a significant relationship between the dependent variable and the independent variable at 0.008 . We therefore reject the null hypothesis and conclude that Environmental Accounting has a significant effect on turn over

Ho2: Environmental Accounting has no significant effect on Return on Capital Employed. 
ANOVA $^{b}$

\begin{tabular}{|l|l|l|l|l|l|}
\hline Model & Sum of Squares & Df & Mean Square & F & Sig. \\
\hline 1 Regression & 955 & 2 & .478 & .030 & $.041^{\mathrm{a}}$ \\
Residual & 47.878 & 3 & 15.959 & & \\
Total & 48.833 & 5 & & & \\
\hline
\end{tabular}

a. Predictors: (Constant): MAA, ENA, ECA

b. Dependent Variable: ROCE

\section{Coefficients $^{\mathrm{a}}$}

\begin{tabular}{|l|l|l|l|l|r|}
\hline \multirow{2}{*}{ Model } & \multicolumn{2}{|l|}{ Unstandardized Coefficients } & Standardized Coefficients & & \\
\cline { 2 - 6 } & $\mathrm{B}$ & Std. Error & Beta & T & Sig. \\
\hline 1 (Constant) & 17.279 & 18.710 & & .924 & .024 \\
MAA & .002 & .013 & .092 & .157 & .085 \\
ENA & 0.00862 & .010 & .086 & .147 & .083 \\
ECA & 0.435 & 0.03 & 0.77 & .243 & .062 \\
\hline
\end{tabular}

a. Dependent Variable: ROCE

The linear equation is given as follows

$\mathrm{ROCE}=17.279+0.002 \mathrm{MAA}+0.008622 \mathrm{ENA}+\mathbf{0 . 4 3 5 E C A}$

From the analysis above, it shows that for every unit increase in environmental accounting coefficients, ROCE increases simultaneously indicating positive effect of environmental accounting on ROCE. This effect is also seen to be significant at $2.4 \%$.

Ho3: Environmental Accounting has no significant effect on Net Profit.

ANOVA

\begin{tabular}{|l|l|l|l|l|l|}
\hline Model & Sum of Squares & Df & Mean Square & F & Sig. \\
\hline 1 Regression & 7.914 & 2 & 3.957 & .290 & $.0457^{\mathrm{a}}$ \\
Residual & 40.920 & 3 & 13.640 & & \\
Total & 48.833 & 5 & & & \\
\hline
\end{tabular}

a. Predictors: (Constant), MAA, ENA, ECA

b. Dependent Variable: NPP

\section{Coefficients}

\begin{tabular}{|l|l|l|l|l|r|}
\hline \multirow{2}{*}{ Model } & \multicolumn{2}{|l|}{ Unstandardized Coefficients } & Standardized Coefficients & & \\
\cline { 2 - 5 } & $\mathrm{B}$ & Std. Error & Beta & T & Sig. \\
\hline 1 (Constant) & 8.049 & 20.539 & & .392 & .321 \\
MAA & .004 & .012 & .202 & .373 & .334 \\
ENA & 1.246 & 1.703 & .397 & .732 & .407 \\
ECA & 1.344 & 2.172 & .308 & .641 & .240 \\
\hline
\end{tabular}

a. Dependent Variable: EVA

$\mathrm{NPP}=8.049+0.004 \mathrm{MAA}+1.246 \mathrm{ENA}+1.344 \mathrm{ECA}$

This shows that for every unit increase in environmental accounting, NPP increase by 0.004 of MAA, 1.25 of ENA by 1.344 of ECA. This effect is however, seen to be insignificant at 32\%. Even though the effect is positive, the insignificance of the effect leads us to accept the null hypothesis that Environmental accounting has no significant effect on Net profit.

\section{Theoretical Inference}

\section{Performance Improvement Theory (PIT)}

Every company is a business unit irrespective of sector or size, the aim of business organisation is to maximize wealth through profitability. Now before the inception of environmental or even the bigger perspective 
sustainability reporting, corporate organisations had their missions and profit motive in operation. Environmental consciousness on the part of an organization involves a lot of expenses as total overhead cost is expected to increase. Some of the costs might be directly relevant to the company operations while some are actually irrelevant in the direct operation of the business. One would then wonder why business corporations spend billions of money on their business environment and employ environmental experts to cost the impact of their activities. The stakeholder theory see this as because the business exist for the stakeholders while agency theory see it that a business exist for its Shareholders. These are not entirely wrong. Analysing this from the core, the business actually exist to make profit, so why would a business venture into activities which might wash down its capital base just to please the Stakeholders or the Agents as the business is considered an entity on its own? This study reveals there are three basic reasons why a business corporation will delve into environmental expenditure, considerations and subsequent reporting as; reputation and Cost reduction:

\section{Reputation}

The environmental generally perceive business organisations with great concern for the environment as "Good". Consequently, firms begin to adjust their corporate policy in order to achieve the "good" image. The good image of a company commands patronage and makes the firm famous even though at immediate cost to the firms. The publication of corporate sustainability information generally, which includes environmental Accounting information, sends the good image of a company beyond its immediate environment. In the long run, the good reputation yields wider market share resulting in increased patronage, increase in market price of their shares and the overall market value. These are reflected in increased in sales revenue, with increased return on capital employed. Thus, a 'sensible' firm adopts environmental accounting and reporting for long run effect on performance.

\section{Cost reduction}

Several environmental laws and regulations are in place in every economy to regulate the operations of manufacturing companies most specifically and generally. In some countries where there are already mandatory requirements for disclosure of environmental information, this seems to be the motivation. The violation of environmental laws by companies attracts penalties and fines which erode their net profit. Since firms are aware of the impact of non-compliance, they choose to comply willingly to enjoin the benefit that the reputation yields rather than bad publicity associated with non-compliance. Even though compliance might be at immediate discomfort to the firms, the reputation from environmental compliance encourages the firm to expand its scope to incorporate environmental accounting and disclosure. This results in wider spread of its reputation thus increased patronage which increases overall corporate performance.

The theoretical inference deducible from our study outcome is the PIT theory. The PIT theory, thus, states that firms are involved in sustainability accounting generally, for the reason of improved corporate performance benefit drivable through good reputation and cost reduction. The implication of this is that, environmental accounting practice of firms is not in a bid to please stakeholders but in attempt to improve overall corporate performance in the long run while winning Stakeholder 'Good' rating. This assertion is justified by our study result as we observed the trend in corporate performance respond positively with the trend in environmental accounting. For instance, our test result in hypotheses one, two and three showed environmental accounting yielded positively on corporate performance of practicing firms. This is further justified by the several works we reviewed globally, which found positive relationship of environmental accounting with corporate performance (Malcom, 2007; Norhasimah, 2016; Ahmad, Waseer, Hussain \& Ammara, 2018; Setyorini \& Ishak, 2012; Okoye \& Ezejiofor, 2013; Adediran \& Alade, 2013; Eboh \& Chukwuka, 2018; Olayinka \& Oluwamayowa, 2014; Iliema \& Ijeoma, 2019). Thus, a firm that wants to improve its overall business performance, to achieve longrun growth and sustainability would not only be environmentally conscious but adopt environmental accounting and reporting as a business strategy.

\section{Findings and conclusion}

Our test results above indicate that Environmental Accounting has significant positive effect on turn over (P-value $=0.0081<0.05 ; 95 \%$ confidence interval), Environmental Accounting has significant positive effect on return on capital employed $(\mathrm{P}$-value $=0.041<0.05 ; 95 \%$ confidence interval $)$ and Environmental accounting has insignificant positive effect on Net profit ( $\mathrm{P}$-value $=0.0457<0.05 ; 95 \%$ confidence interval). These results indicate that as companies practice environmental accounting and reporting, their profitability level begins to increase owing to increase in reputation which yields increase in sales revenue and returns. Thus this study concludes that environmental accounting practices have significant positive effect on corporate performance of Oil and Gas firms in Nigeria. The study therefore recommends that:

- Corporate organizations should extend their management accounting and financial reporting systems into environmental accounting as a way of ensuring long-run corporate sustainability. 
- Companies should aim for increased market share and corporate reputation by improving on their environmental performance to enjoy the advantages of increased revenue, return on capital investment and profitability in the face of constant competition.

- More attention should be paid by government and standard setting Bodies on issues of environmental concern by instituting mandates that compel firms to practice environmental accounting and reporting in Nigeria. Also corporate organisations should be compelled to submit Environmental Impact Remedy plans as part of requirements before commencement of business. This will ensure the practice of environmental accounting from the inception of a business.

\section{REFERENCES}

Adediran, S.A., \& Alade, S. O (2013). The Impact Of Environmental Accounting On Corporate Performance In Nigeria. European Journal of Business and Management. ISSN 2222- 1905 (Paper) ISSN 2222-2839 (Online) 5(23). Retrieved from www.iiste.org

Ahmad, M. Waseer W.A, Hussain S., \& Ammara U. (2018). Relationship between Environmental Accounting and non-financial Firms Performance: An empirical analysis of selected firms listed in Pakistan Stock Exchange, Pakistan. Advances in Social Sciences Research Journal, ISSN 2055-0286, 5(1). DOI: http://dx.doi.org/10.14738/assrj.52.4139

Amedu, J.M., Iliemena, R.O. \& Umaigba, F.T. (2019). Value relevance of sustainability reporting in Nigerian manufacturing companies. Journal of Global Accounting, 6(2), 131 - 147. www.researchgate.net

Bewley, K., \& Li, Y. (2000). Disclosure of environmental information by Canadian manufacturing companies: A voluntary disclosure perspective. Advances in Environmental Accounting and Management, 1, 26-45.

Cooper C, Taylor P, Smith N, Catchpowle L. (2005). A discussion of the political potential of social accounting. Critical Perspectives on Accounting. 16(7):951-974

Freedman, M. \& Patten, D.M. (2004). Evidence on the pernicious effect of financial report environmental disclosure. Accounting Forum, 28, 27-41

Global Reporting Initiative (GRI). (2002) Sustainability Guidelines on Economic, Environmental and Social Performance.

Henderson, S. \& Pierson, G. (2010). Issues in financial Accounting French Forest, NSW: Pearson Education Australia.

Hughes, S., Anderson, A., \& Golden, S. (2001). Corporate Environmental disclosures: Are they useful in determining environmental performance? Journal of Accounting and Public Policy, 20 (3), 1-17.

Iliemena, R. O. \& Amedu, J.M.A. (2019). Effect of standard costing on profitability of manufacturing companies: study of Edo state Nigeria. Journal of Resources Development and Management, 53, 28 - 34. www.researchgate.net

Iliemena , R. O. \& Ijeoma, N. B. (2019). Effect of sustainability reporting on firm performance. Unpublished seminar. School of postgraduate studies, Nnamdi Azikiwe University.

Iliemena, R. O. C. \& Okolocha, C. B. (2019). Effect of audit quality on financial performance : evidence from a developing capital market. International Journal of Recent Research in Commerce Economics and Management (IJRRCEM), 6(3), 191-198. www.paperpublications.org

Juhmani, O. (2014); Determinant of Corporate Social and Environmental Disclosure on Websites: The Case of Bahrain. Universal Journal of Accounting and Finance: 2(4) Accessed at http://www.hrpub.org doi!10.13189/ujat.2014.020402.

KPMG, United Nations Environment Programme (UNEP) (2006) Carrots and Sticks for Starters'. Current Trends and Approaches in Voluntary and Mandatory Standards for Sustainability Reporting. Parktown:

Mabogunje, A.I (2007). Health Challenges of Nigerian Urbanisation Paper Presented at 9th Benjamin Olukayode Osuntokun memorial. Lecture Presented at University College Hospital (UCH) Ibadan.

Malcolm, S., Khadijah Y., \& Ahmad M. A. (2007). Environmental disclosure and performance reporting in Malaysia. Asian Review of Accounting, 15(2), 185-199. Retrieved from https://doi.org/10.1108/13217340710823387

Mitchell, J., Percy, M., \& McKinlay, B. (2006). Voluntary environmental reporting practices: A further study of "poor" environmental performers. Australian Journal of Corporate Law, 19 (2), 64-81.

Murray, A. (2010). Do markets value companies' social and environmental activity? An inquiry into associations among social disclosure, social performance and financial performance. $\mathrm{PhD}$ thesis. University of Glasgow. Retrieved from http://theses.gla.ac.uk/1770/

Murray, A., Sinclair,D., Power, D. \& Gray, R. (2006). Do financial markets care about social and environmental disclosure? Further evidence and exploration from the UK. Accounting, Auditing \& Accountability Journal, $19(2), 228-255$.

Norhasimah (2016). The effects of environmental disclosure on financial performance in Malaysia. Procedia Economics and Finance, 35(1), 117-126. 
Nze, D. O., Okoh J., \& Ojeogwu, I.C. (2016). Effect of corporate social responsibility on earnings of quoted firms in nigeria. ESUT journal of Accountancy 1, 260 -267.

Okoye, P.V.C. \& Ezejiofor, R.A. (2013). An appraisal of sustainability environmental accounting in enhancing corporate productivity and economic performance. International Journal of Advanced Research, 1 (8), 685 693.

Schaltegger S, Burritt R, Petersen H. An introduction to corporate environmental management: Striving for Sustainability. Greenleaf Publishing: UK; 2003

Yakhou, M \& Dorweiler, V (2004). Environmental Accounting: An Essential Component of Business Strategy. USA: John Wiley and Sons Ltd. 